\title{
Re-imagining Funerary Rites in the Context of Covid-19
}

\author{
Nelson S. Ratau \\ Department of English, University of Zululand \\ KwaDlangezwa 3886 \\ South Africa \\ E-mail: rataun@unizulu.ac.za
}

\author{
Ntsofa C. Monyela \\ Department of Anthropology and Development Studies \\ University of Zululand \\ KwaDlangezwa 3886 \\ South Africa \\ E-mail: monyelan@unizulu.ac.za \\ Neo R. Mofokeng \\ Department of Anthropology and Development Studies \\ University of Zululand \\ KwaDlangezwa 3886 \\ South Africa \\ E-mail: mofokengn@unizulu.ac.za \\ Doi: https://doi.org/10.46222/pharosjot.102215
}

\begin{abstract}
Covid-19 has brought about unsuspected possibilities and death on a large global scale since its advent on the shores of the global community in early March of 2020. The novel pandemic has undoubtedly challenged and changed the normative operations of the social, political and economic activities all across the globe. Religious fraternities and activities have experienced challenging dynamics in how fellowship and worship are practised. Businesses and the entertainment industry have their share of suffering and enduring the suspending effect that has since been forcefully occasioned by the strategic global lockdown. The labour market metrics have realised a drastic decline due to companies closing down owing to the challenges that Covid-19 has rendered against their financial fragility and profit share. Academic institutions have also seen drastic challenges and a need for change in how they perform their curricula duties in the unpredictable context of Covid-19. Evidently, the advent of the Coronavirus has pointedly offered the nations of the world an opportunity to re-imagine a number of issues and social conducts. With millions of people dying across the globe, funerals have taken a new, strange turn in how the rites of passage for the deceased are practised. In light of this, the current essay presents the argument around re-imagining funerary rites in the Covid-19 context. The paper adopts Victor Tuner's theoretical assumptions of ritual purported in his text entitled The Ritual Process: Structure and Anti-Structure, so as to theoretically problematise the idea of re-imagining funerary rites in the undesirable 'new normal'? situation of Covid-19.
\end{abstract}

Keywords: Covid-19 context, Culture, Cultural adaptation, Funerary rites, New Identities, Ritual, Spirituality, Ubuntu.

\section{Introduction}

The world has experienced a number of detrimental outbreaks such as the Black Death (13461352), the Great Plague of London (1665-1666), Spanish flu (1918-1920), the Influenza Pandemic (1957-1958), the Human Immunodeficiency Virus (HIV) (1980s), and the Severe Acute Respiratory Syndrome of 2003 (see World Health Organisation, 2020; Senthilingam, 
2020). Covid-19, which had its first case in China in 2019 at a seafood market in the city of Wuhan, from an unknown animal source, infected over 9,800 people and killed 210 people in less than a month (Senthilingam, 2020). It has caused death on a large global scale. The pandemic has thrust upon the people of the world the need for strategic regulations to curb the spread of the virus. People's lives have since been dramatically disrupted in an unprecedented manner. In Africa, a continent still in a process of transformation in many respects and plunged in socio-economic problems such as poverty, crime and unemployment, the Coronavirus has put the continent's movements towards realising a better a life for all its people on a precarious hold. Hence,

\begin{abstract}
With the outbreak of the pandemic in Africa, governments across the continent took very stringent measures aimed at containing its spread. Among others, these measures included a ban on all public gatherings, the indefinite closure of public institutions including schools and universities, suspension of all air travel, shutdowns cities and towns across countries, thus restricting movement of population, and the launch of testing programmes to identify, isolate and treat infected people (UNESCO, 2020:5).
\end{abstract}

In his chapter-turned article, which is entitled "The Emergence of the Lockdown University: Pitfalls, Challenges, Opportunities", Hlatswayo (2020:134) fittingly states: "COVID-19 has fundamentally disrupted our way of life and has resulted in many countries battling to respond to the pandemic through shutting down the transport system, schools, universities, companies and the economy in general". The Coronavirus pandemic has seen millions of people infected, hospitalised and quarantined, and others dying by the thousands (see World Health Organisation, 2021). Businesses and entertainment industries have since started to see a dry season, where many companies closed shops, entertainers had no jobs, resulting in no income as large gatherings such as concerts, which are their workplaces, have since been prohibited. South Africa (SA) recorded its first COVID-19 case on 5 March 2020. Consequently, the country declared a State of Disaster on 15 March 2020, a strict 3-week 'lockdown', effective from 26 March 2020 - which was subsequently extended until 30 April 2020 - and a 5-level 'risk adjusted strategy', effective from 1 May 2020. South Africa's lockdown measures have had a profound impact on the country's social and economic fabric (Singh, 2020). The lockdown suspended many activities and disrupted several norms as a precautionary measure to curb the spread of the novel Coronavirus.

With the government having put forth regulations and prohibitions such as the sale of alcohol (as per the alert level imposed), large gatherings at recreational facilities, public gatherings such concerts, church gatherings and large numbers at funerals (i.e., beyond 50 individuals) to manage the health crisis came a plethora of criticism and questions of the government's understanding of the socio-economic conditions in which ordinary citizens live. Case in point is Dr Velaphi Mkhize, a Zulu spiritualist and healer, who in an article published by SowetanLive entitled "Lockdown has offended African burial rites", said: "When Covid-19 arrived, it found black people practising cultures and traditions and following certain processes to do things. It arrives to a rainbow nation. When coronavirus arrived it proved that we are not a rainbow nation because it arrived with laws that affect only a particular race, which is African people" (see SowetanLive, 2020).

With most sectors of the economy forced to close to mitigate the risk of the disease spreading, people have been forced to choose between their lives and their livelihoods. Rising levels of hunger and desperation in the country have led to accusations that the government has 'failed to understand the severity of the everyday lived realities of the majority of South Africa's poor people' (see Mail \& Guardian, 2020; Singh, 2020). The lockdown restrictions and regulations coined and put forward by the government on how funerals must be conducted have caused considerable disruption, anxiety and misunderstandings around funeral practices (see SowetanLive, 2020). There are ongoing studies conducted by scholars such as Cardoso, Silva, Santos, Lotério, Accoroni, and Santos (2020) looking into how the lockdown regulations have disrupted funeral practice, and it is evident that the funeral regulations are colliding with 
local cultural sensibilities and historically established practices (see SowetanLive, 2020). The lockdown regulations, which are necessary precautions to prevent the wide spread of the virus have seen people bury their loved ones in novel, if not strange ways. An example of this being a case of a local community in Bizana in the Eastern Cape where the attendees and family members were angered by the manner in which their loved one's burial was conducted; the attendees complained about having practiced funeral rituals without the body present. There are many cases such as the one in Bizana, where people were appalled by the strangeness with which funerals and burials are now conducted. The lockdown regulations informed by the 'invisible enemy' have brought about change to funeral rites in South Africa and elsewhere in Africa; and this change of long-standing traditions is particularly difficult for the Africans who embrace social support and community kinship (AED Attorneys, 2021).

\begin{abstract}
Traditional experts have slammed the Covid-19 rules and regulations, saying they were hindering families from practising their African culture and traditions. Since the lockdown began in March, many traditional ceremonies were disrupted by police who even threw away meat and traditional beer (see SowetanLive, 2020).
\end{abstract}

To take stock of how the pandemic affected funerals, one can list issues such as: communal support system and obligations, customary family and relative mourning practices, the slaughtering of animals that a funeral always occasioned were brought to suspension. Alternatively, there are those cultural experts who assert that to slaughter a cow or animal for a funeral is no longer necessary. This is because in the distant past, African people slaughtered a beast not just for meat, but for the purpose of using the hide as a 'coffin'; they wrapped the cadaver with the hide for burial (see SowetaLive, 2020).

There are scholars who view the pandemic as, to use a cliché clause, 'a blessing in disguise' for governments, institutions to re-evaluate their approaches, traditions on how they conduct their day-to-day business (Khan, Shan \& Shan, 2021; Mousazadeh, Paital, Naghdali, Mortezania, Hashemi, Niaragh, Aghababaei, Ghorbankhani, Lichtfouse, Sillanpää, \& Hashim, 2021; Hlatswayo, 2020). The latter is a rather bizarre and 'absurd' stance to view a virus, that has taken many lives all across the globe, as offering opportunities while humanity have lost so much. It is a statement that those people who lost their loved ones would not kindly listen to. However, the people who make such views mean no insensitivity towards the loss and pain that many people experience in the pandemic, rather they are offering guiding pragmatic views on how to work out those issues in society that need to be reshaped for economies and academies to stay relevantly operational.

The current paper plays host to the idea of Covid-19 as having occasioned an urgent space where people of (South) Africa have to re-imagine certain aspects of their traditional and cultural practices so as to be relevant in the unforgiving Covid-19 situation. In this paper, we look at how the Covid-19 context has brought about the urgent need for people to re-imagine how they the observe the practice of funeral rituals. The paper discusses the African cultural concept of death; the concept ritual; presents a review of the different types of rituals as practiced by Africans (funerals and related rituals); it looks at issues such as Ubuntu, identity, culture and spirituality, which are intricately connected to the concept of death, at least in the African context. By 're-imagining funerary rites', it is meant as a scrutiny on how in the Covid19 context funerals are conducted and how those parts of the rituals which were practiced with ease under normal circumstances are now met with challenges and 'suspension' due to the virus, and could be 'repackaged' for contextual relevance. Ultimately, the paper points out that rituals are not primarily permanent in how they are practiced, save for their purposes.

\title{
Establishing the Context
}

This paper is a desktop study, a conceptual study that relied heavily on already existing literature. We reviewed literature related to the concept of funerary rites in the context of Covid19; the context which inflects funerary rites. Basically, a desktop study involves a selective 
collation of documentary data; to produce an outline conceptual model (Bamford, 2020). Additional, Bamford (2020) asserts that a desktop study refers to an investigation that is carried out purely by desk based research. The study also followed a document analysis methodology to review concepts and issues such as Ubuntu, the African cultural concepts of death; the theoretical conceptualisation of ritual in an African context; religion and spirituality as related to ritual; culture; identity; and the 'new normal'. The concepts and issues were purposively sampled as they are related to the key concept or issue of funerary rites. These concepts and issues provided the paper with the necessary and primary data.

In a nutshell, secondary sources in the form of journal articles, dissertation, theses, print books and other forms of sources which inform the crux of the paper's argument were consulted and analysed in order to conceptualise the topic and related issues. Our frame of analysis was guided by Masoga's (2017) Afro-sensed approach, which argues that African contexts and spaces present unique opportunities in the discourse of knowledge development. Additionally, as Masoga guides, appended to the latter assumption is that "While one admits the nomothetic characteristics of knowledge at the same time one has to look at its idiographic perspective of knowledge" (Masoga cited in Shokane, Masoga \& Blitz, 2020:111). The authors further condense the Afro-sensed approach in light of the fact that "one has to strike the balance between universal and specifics of knowledge development" (Shokane, Masoga \& Blitz, 2020:111). Moreover, most relevant and potent is Masoga's assertion cited in Shokane, Masoga and Blitz (2020:112) that the Afro-sensed approach to research enables one to realise that "some of this knowledge brings pleasure, reinforces tradition and belief systems and gives a sense of belonging and relatedness."

\title{
Ubuntu (or African Humanism)
}

Ubuntu is a word that has its origin in the Bantu language of southern Africa (Edeh, 2015). Ubuntu is an African philosophy, a worldview, or an outlook of the world. Edeh goes on to describe Ubuntu in the following way: "In southern Africa, the idea of humanism has been identified variously as Ubuntu. Ubuntu is seen as an ethical philosophy which is centred on the people's allegiances and relation with one another" (Edeh, 2015:206). Essential here is the view that the African philosophy of humanism is concerned primarily with people, and how people relate with or aid each other. "Ubuntu lies at the heart of the African way of life and impacts on every aspect of people's well-being" (Lefa, 2015:4). Rafapa (2005) in his thesis studying the representation of African Humanism in the narrative writings of Es'kia Mphahlele, views African Humanism aligning with a continuous, holistic view of reality, from an African perspective. The philosophy of Ubuntu or African humanism could be aptly captured in the Sesotho adage: "motho ke motho ka batho/motho", which translates into 'a person is a person because of (an)other people/person' or the Nguni version of the adage: "umuntu ngumuntu ngabantu" - hence the Sotho word Botho, is an equivalent of the Nguni word Ubuntu.

\begin{abstract}
Ubuntu has its origins in the African conception of being. The fundamental tenets of Ubuntu are in a nutshell a philosophy or worldview that constitute the spiritual cradle of African religion and culture. Khoza goes on to opine that Ubuntu finds expression in virtually all walks of life - social, political and economic. More than anything, Ubuntu is a comprehensive mode through which reality is constructed and shared (Khoza, 2005:xx-xxii).
\end{abstract}

Congruent with Khoza's defining description of Ubuntu is Mphahlele whose view of Ubuntu captured in his The Fabric of Culture and Religious Beliefs (2002) cited in Rafapa (2005:19): "African humanism differs with scientific humanism in its outlook on religion (Mphahlele suggests) because (being originally a religious state of mind) today "African humanism still has a religious base" with morality remaining the primary criterion to assess the ethics of conduct." In light of the quotation above of significance is the moral and religious nature of Ubuntu or African Humanism, and ethical conduct, which project the philosophy as concerned with ensuring that people are conscious of one another, especially in the things they do; one is kept in check in their conduct by the collective philosophy of Ubuntu; the conduct must 
maintain a moral sensibility and order, so to guard against offending other people. Ubuntu is then an injunction to discipline and good regard and care for others. Mphahlele as cited in Rafapa (2005:18) states that "In African humanism it is man's present moral and spiritual life that deserves our attention and care."

The philosophy has multiple dimensions encompassing the moral, philosophical, rational, psychological and social. Ubuntu is characterised by values such as caring, reciprocity, sharing, compassion, hospitality, cohabitation, cooperation and tolerance (Lutz, 2008; Khoza, 2005). Pithily, Sebola and Mogoboya (2021:368-369) view Ubuntu as a philosophical view that "condenses both an ethical stance and understanding which emphasis human dignity, concerns and capabilities". Ubuntu is crucially functional philosophy which is "used politically to emphasize the need for unity in consensus in decision making as well as the need for a suitably humanitarian ethics to inform those decision" (Edeh, 2015:207). Sebola and Mogoboya (2021:369) paraphrasing Edeh (2015) break down the essence of African humanism as a philosophy that "inflects African culture, customs and traditions as deeply rooted in an ethical understanding of human value and the essence of coexistence".

In a nutshell, Ubuntu is a philosophical African worldview which is predicated on basic human values such as tradition, culture and customs, and appreciates human social interdependence and collectivism as opposed to independence and individualism. Ubuntu resonates with the Kenyan notion of Harambee as they both cherish the concept of working together among people - social cohesion/unity (see The Namibian, 2016). The philosophy also covers and appreciates the affirmation of being and belonging as an ethical aspect, in a sense that one is responsible to be an ethical person so as to well-represent the community the belong to. For this current paper, the philosophy of Ubuntu provides a relevant and significant background as well as the philosophical understanding of the context of our argument. To coalesce all that has been mentioned about Ubuntu, Sebola (2021) citing Rafapa submits that African Humanism is primarily a premise upon which Africans generally display their completeness as humans.

\section{The African Cultural Conception of Death}

Death is all peoples mutual fear, a common enemy; albeit, human beings across different cultures of the world view death differently. This section, therefore, presents a brief literature review on the African conception or view of death. The best way to launch a discussion on how death is conceptualised in Africa is by first discussing, briefly, the African view of life. Njoku cited in Asoquo presents or rather, summarises the concept and view of life by African on three planes as follows:

\footnotetext{
Firstly, God is the originator of life, the creator of man, the universe and the sustainer of creation. Secondly, the ancestors play an important role in the communal life. They are not cut off from the living, for they may still reveal themselves in dreams or appear to their living relatives to guide or correct them. Thirdly, life is a communal affair. It involves a relationship and communion between man, God, ancestors, divinities, other men and the land. This relationship must be based on certain rules and regulations for it to succeed (Asoquo, 2011:171).
}

Succinctly put, the view of the concept of life in Africa, by Africans reveals that life for African people is not a solitary affair left only for the living to deal with, rather, a dynamic, collective and constant connection and communication between three entities, namely; man, the ancestors and God. Mbiti (1980) sees the concept of life, human life, as related to the concept of time. Mbiti (1980) opines that the concept of time essentially instantiates life as a rhythmic cycle which takes in the issue of birth, growth phases of a person such as puberty, initiation, marriage, procreation, old age, death, entry into the community of the departed, and ultimately entry into the company of the spirits. 
Death is an unescapable and unalterable fact of life. Every race holds a unique view of death. For instance, in ancient Greece, there was a cultural belief with regards to death and what happens to a deceased person (where does a dead person go). This is captured in the Greek mythology of the ferryman, who is known as Charon, the son of Erebus and Nyx (Night) (Gazdac, 2013). Charon's significance/job was to ferry the soul of a deceased person who would have had gone through the rites of burial (ritual of burial) (Georgieff, 2017; Gazdac, 2013). The rite of burial is the preparation of a dead person's body for burial. Now, in the Greek mythology of the ferryman, Charon, the most important part of the ritual of preparing the body of the dead for burial was finally putting a coin in the corpse's mouth for Charon (the ferryman) to take as payment for his services of ferrying the soul of the deceased person to the land of spirits (Gazdac, 2013). It was believed that that when a person dies, he or she is taken across the river by the ferryman (Charon son of Erebus and Nyx, is also known as Night) from the world of the living to the world of spirits (Georgieff, 2017; Gazdac, 2013). Accordingly, Schmidt cited in Baloyi (2014:7) uses the metaphor of 'the passage to the spiritual world which is described as crossing a river'.

The African view of death holds that death is not a finality. Temples cited in Iteyo (2009:155) proclaims that "there is belief that the dead fathers of the community still exist but in spirit form". This rejects any view that may see death as an ultimate termination of a person's physical existence or presence on earth because it teases out the view that death is in fact a vehicle that occasions a person's move from the earthly, physical realm to a spiritual realm of the ancestors and spirits. In a way, when a person dies, he or she becomes a spiritualised being who now dwells in the unseen and unknown realm beyond that of ordinary human beings; and as Temples posits, the spiritualised person now mounts a higher plateau compared to that of the living human beings, "being higher on the ontological hierarchy, participating to a certain degree in the divine force" (Temples cited in Iteyo, 2009:155). This is congruent with Mbiti's (1980) view of life in relation to death. Though causing the deepest and most hurting grief on the family of the departed, death for Africans is mere departure or transition rather than the termination of a life; it is an entering-into the next stage in the cycle of life. According to Enkore and Lanre-Abass (2016:369), "the African belief system, life does not end with death, but continues in another realm." Congruently, Eyetsemitan cited in Enkore and Lanre-Abass (2016:370) posits that

\begin{abstract}
...the traditional African belief system is also referred to as ancestor worship and is based on an understanding that the life course is cyclical and not linear. Based on this system of belief, those who are dead are alive in a different world and can reincarnate (and return to this world) in new births.
\end{abstract}

Every race or nation on earth holds a particular view of death which is in some way unique to that race or nation. It is that view of death as held by that race or nation that operates as a guiding principle on how a dead person is to be buried/sent-off, and there is value placed on the manner of these practices. Therefore, it is clear that Africans believe in the spirit of the dead. Believing in the spirit of the dead here means acknowledging that the dead are spirits that live. Iteyo (2009:156) observes that "belief in the spirits of the dead provides a basis for most of the practices that take place from the time one dies to the end of the mourning period"; and Oruka cited in Iteyo (2009:156) declares that the "spirits of the dead are to be feared since, if one does not comply with the customs, then he/she is haunted by them". The foregoing views on the African cultural conception of death laconically launch the issue of ritual in death. "The death of a person in Africa, for example, is a significant event that can affect the entire structure of society" (Smith, 1987:28); and this inspires the practice of rituals related to the burial of a person. Ritual is in fact one of the central reasons that bolster the view that Africans do not view death as a finality, including the Maghrib region, where death is accepted and understood (especially in the Arabic culture), and is regarded as part of their faith in God. Evidently, Al-Meshhedany and Al-Sammerai posit that "in the Arabic culture has many meanings. It may mean that one is to stay in heaven or hell. To some, death is a transitory state until the day of al-hesaab, (the day human meet Allah)" (Al-Meshhedany \& Al-Sammerai, 
2010:12). Therefore, the funerary rites which are reverently and sacredly observed upon the death of a person, reveal that the living still value the dead, and regard the dead as not 'really' dead. If this were the case, that is, if the living African people thought their dead 'really' dead, they would not place so much value and effort in funerary rites (ritual and funerary rites are discussed in detail in a proceeding section). To submit the issue of the African view of death, Iteyo, who studies the cultural and spiritual beliefs of the Luo people of Kenya observes that

The belief is that a human being is made up of visible (the body) and invisible parts (tipo). The union of the two parts forms human life. At death the body perishes, but tipo becomes the spirit. The spirit retains the individual identity, but becomes more intelligent and powerful than in the previous life; and this is the premise upon which the African view(s) of death or dying is foregrounded (Iteyo, 2009:156 emphasis added).

Baloyi and Makobe-Rabothata appositely condense the African conception of death by stating that "an African perspective death is a natural transition from the visible to the invisible spiritual ontology where the spirit, the essence of the person, is not destroyed but moves to live in the spirit ancestors' realm dead. It signifies an inextricable spiritual connection between the visible and invisible worlds" (Baloyi \& Makobe-Rabothata, 2014:232).

\title{
Theoretical Framing
}

There are several theories of ritual. The current paper has selected Victor Turner's Theory of Ritual as purported in his critical text The Ritual Process: Structure and Anti-Structure (1969). Alexander (2021), writing on the online Encyclopaedia Britannica, provides this biographical and historical background on Victor Turner's theory and study:

\begin{abstract}
From the 1960s through the early 1980s, the classic structural functionalist view of rites of passage was challenged and revised. The charge was led by the British Anthropologist Victor Turner, who acknowledged the contribution of structural functionalism to the study of rites of passage and of the broader category of ritual while pointing out its limitations. In his study of African rites of passage, The Ritual Process: Structure and Anti-Structure (1969), Turner revealed the drama and flux of everyday social life and highlighted the agency of rites in effecting social change, which he considered to be their fundamental role.
\end{abstract}

Alexander goes further to offer a compressive glimpse into the genesis of Turner's work by acknowledging that he (Turner) started his study of rituals by building upon van Gennep's observation that rites of passage and other rituals are liminal in that they temporarily extricate participants from their social statuses, Turner argued that rites of passage are antithetical to the existing social structure and "subjunctive" because they invite new possibilities (Alexander, 2021). Rites enable participants to experiment with alternative social relations or to invent new ones.

Though studying African rituals as an outsider, Victor Turner pioneered theoretical anthropology on the study of social aspects such as culture and religion and ritual, with a special focus on the African villages of Zambia, Tanzania and others. Bigger offers this information on Turner and his study of culture and rituals:

\begin{abstract}
Victor Witter Turner (1920-1983), working with his wife Edith Turner, was an anthropologist deeply concerned with ritual both in tribal communities and in the contemporary developed world. His early fieldwork in African villages in the 1950s (Turner 1962) was typical of the career development of field anthropologists at that time. He developed a special interest in rituals, seeing these as social drama[s] in addition to the religious expression of the sacred (Bigger, 2009:209 emphasis added).
\end{abstract}

Turner focused on the concept of limen, 'threshold' and the term liminality (Bigger, 2009). The concept of 'liminality', much like the phenomena to which it is generally held to ascribe, is itself 
passing through something of a transitional phase (Andrews \& Roberts, 2015; Bigger, 2009). Turner (1969) posits that liminality has to do with death. Furthermore, Andrews and Roberts posit that "what is understood by the term liminality today encompasses a wide array of meanings and theoretical associations that go far beyond those more traditionally linked with anthropological discussions on ritual, performance, pilgrimage and cross-societal 'rites of passage'" (Andrews \& Roberts, 2015:132).

Turner's theory of liminality finds acquired inspiration from the work of the French ethnologist, Arnold van Gennep (Andrews \& Roberts, 2015; Bigger, 2009). But what are the basic tenets of Turner's theory of ritual? Fundamental in Turner's theoretical conception of rites of passage (rituals) is his perceptions of these acts as having the potential agency to effect social change (Turner, 1969). Worth mentioning here, in the undertones of Turner's conception of rites of passage, is the African philosophy of Ubuntu, which is variously referred to as African Humanism; especially when he submits that rites of passage temporarily extricate (interestingly connoted in the word extricate is the word 'free') participants in a rite from social structure (that dehumanises or enforce hierarchies among people), they (rites of passage) humanise by returning to participants the common basis of their being (Turner, 1969). Additionally, interestingly appended to the African philosophy of Ubuntu in Turner's theory of rituals is his assertion on the spontaneity and direct way in which people partaking in rituals experience one another as equals - he (Turner) terms this phenomenon communitas. Accordingly, Turner (1969) argues that rites of passage are antithetical to prevailing fashions of social structure and "subjunctive" in the sense that they invoke new possibilities. In other words, rituals are constantly experiencing change with regards to their method, although they still retain their purpose. Since rites of passage are in a state of constant flux and liminality, they impact some of the basic Christian teachings in a positive way, teachings such as humility and unity of people; because during the practicing of a rite of passage participants show obedience of rules and principles and follow certain prescribed forms of conduct and dress, and sometimes adopt particular mannerism of speech.

\section{The Concept of Ritual in an African Context}

This section presents a brief review of ritual by way of definition and description of what ritual is, thus conceptualising it; the section also presents the different classifications of rituals, and presents specific details about funerary rites.

According to Arnold Van Gennep (1960:2), "The life of an individual in any society is a series of passages from one age to another and from occupation to another." Africans have always acknowledged their ancestors by preserving their cultural creations and belief in celebrating and performing rituals (Ukwamedu, 2018:25). And "wherever there are fine distinctions among age or occupational groups, progression from one group to the next is accompanied by special acts, like those which make up apprenticeship in our trades" (Van Gennep, 1960:3). Mbiti $(1969: 149)$ states that "there are many, and often complicated ceremonies connected with death, burials, funerals, inheritance, and the living dead, among others." A ritual can be aptly defined as religion in action, and a symbolic practice conducted by the relations of the deceased as spiritual mannerism of 'sending off' the deceased with dignity to the satisfaction of the family and relatives and the community. Burkert cited in Masoga defines ritual as "Forms of non-verbal communication" and "patterns", and Masoga adds that there are accompanying motives (Masoga, 2020:135).

According the anthropologist and theorist, Victor Turner:

In all societies, when a person dies, family, friends, and neighbors respond in structured, patterned ways to the death. Cultural guidelines determine the treatment and disposal of the body and prescribe a period of mourning for close relatives. Death ritual, like much of human behavior, is an expression of a cultural blueprint, of attitudes, values and ideals passed down by parents, 
and their parents, which an individual learns as a member of society (Turner, 1969).

The researchers are of the view that ritual is a practice that denies hysteria or on-the-spot adaptation of new ways, it is meticulously procedural and well-organised, and sacred. A ritual is a stabilising aspect of faith and a habitual action that formalises the lives of communities in which is practiced (Margaret Holloway et al., 2013).

From military to organised crimes groups, from cults to prostitution and bike gangs, a person who dies identifying with these groups is buried with unique, "satisfactory" rites held and practiced by the groups performed so as to send off the deceased with at least some dignity. These are not trivial matters, but funerary rites that these groups find appropriate for them to bury. Van Gennep is cited by Turner (1969:359) as defining rites de passage as "rites which accompany every change of place, state, social position and age".

Segal (1983:327) submits the following view of ritual:

Ritual serves to express those cosmic beliefs-not for the scientific purpose of explaining or controlling the cosmos but for the existential purpose of giving human beings a place in it. Ritual serves simultaneously to express beliefs about society-not only for the functionalist purpose of keeping human beings in their social place but also for the existential purpose of giving them a social place.

Turner (1969:358) "posits that rituals manage transitions for individuals and collectivities. Such transitions are key to the shaping of both temporal and social experience." Other scholars describe ritual as involving sacred, alternatively secular symbols, and as stereotyped communication which ultimately reduces anxiety and prepares a person for an action, and that it socially coordinates the preparation for action among peoples (Cohen, 2002; Wallace, 1966). Ritual is therefore an action that inflects on a person, people and society by providing a curative attitude to people's minds, social situations, consequently affording people an opportunity to align or realign themselves with the natural, supernatural or spiritual entities. In congruency to the preceding interpretation of ritual, Gluckhan cited in Cohen (2002) outlines the significance of ritual thus: "social attributes of ritual and the importance of supernatural sanction in enforcing conformity". Congruent with Gluckan in this regard is Cohen's (2002) assertion that ritualisation denotes the performing of prescribed actions solely with the expectation that the ritual behaviour will direct and correct or amend social relationships, and consequently help people to secure blessings, purification, protection and prosperity. Ritual is, therefore, not an act performed ordinarily and haphazardly or without meticulous order and method (but the method changes with the times), and purpose (which is retained) (Masoga, 2021). On the contrary, ritual is an act that is performed sacredly, reverently and by employing mannerisms of performance that behove its sacred and spiritual magnitude and importance in the matrix of social setting and lives of people. Ritual creates and affirms social interactions (Burkert cited in Masoga, 2020). There are different types of rituals and they are discussed under the topic Re-Imagining Funerary Rites in the Covid-19 Context.

\section{Different types of rituals}

There are many forms of ritual in African society, and these rituals are performed for various purposes. Van Gennep posits: "Transition from group to group and from one social situation to the next are looked on as implicit in the very fact of existence, so that a man's life comes to be made up of a succession of stages with similar ends and beginnings: birth, social puberty, marriage, fatherhood, advancement to a higher class, occupational specialization, and death." (Van Gennep, 1960:3). What Van Gennep has listed here are different classes, positions or stages that an individual is likely to be in and transition from, and for every transition there is a specific ritual practiced to facilitate the move from stage to the next. In his book, Studies on Indigenous Knowledge Systems, Masoga, whose fields of speciality are African Indigenous Knowledge, Ritual and Religion, discusses different types of rituals, such as baptism ritual, 
holy communion ritual, marriage ritual, death and cleansing rituals (Masoga, 2020), including, initiation ritual, funeral ritual, crisis ritual and calendrical ritual. This section is not aimed at providing an exhaustive presentation of different types of rituals. Rather, it is to point-out how diverse rituals practiced in societies, especially in the African context. Masoga (2020:139) counsels that if practiced from an Afro-sensed, such rituals "facilitates transitive categories." For example, initiation, funeral, marriage and baptism are regarded as rites of passage - a shift from one stage of life to another stage of life. Through these rites of passage new identities, new priorities, new values and new communities are constructed - because rituals are human constructs by their very nature.

Turner (1969) argues that when practiced, rituals manage transitions of the individuals and the collective. At funerals, they are performed for this purpose of facilitating the "transition" because of the belief that death "is a natural transition from the visible to the invisible or spiritual ontology where the spirit, the essence of the person, is not destroyed but moves to live in the spirit ancestors' realm" (Baloyi \& Makobe-Rabothata, 2014:235). In his book, Listen to Africa: A Call from L. S. Senghor, Nespoulous-Neuville (1999:76) defines initiation ritual as "a complex ritual teaching intended to resolve the primal and agonizing conflict between man's lust for life and his certainty of death." In this case, initiation becomes a rite of passage that creates person's new identity and guides him or her into the new stage of life and its triumphs, trials and tribulations. Same applies to a marriage as a rite of passage; it signifies progression from one stage of life into another. In the African context, marriage is a unifier of two families; and through this unifying rite of passage (marriage) new identities, new communities, new norms and values are constructed. For example, when a female gets married, she becomes ngwetši in Sepedi, or a sister-in-law in English. In the context of the baptism ritual, one who participates in it is believed to be undergoing a process of transition, a process of rebirth or being born again. Also in this occasion, new identities, norms and values as well as priorities emerge. As pointed out above, the current essay focuses specifically on the funerary rites in an effort to call for the re-imagination of funeral rites in the context Covid-19 pandemic.

\section{The Religiosity and Spirituality of Ritual}

According to Asih, Setini, Dharmmesta and Purwanto (2020:4023), "Religiosity is a group activity with a certain behavior that tends to be social, doctrinal, and characterized according to certain groups/religions". Religion or religiosity also informs one's behaviour or social conduct and cultural practise in the different spheres of life. Rituals are a group activity, shared among people who identify as sharing common beliefs systems (religion). For example, in "Most South African Christian denominations" they are certain rituals that are practiced "related to birth (baptism), church unity (holy communion), marriage and death" (Masoga, 2020:143). Lepherd (2014) describes spirituality as that which includes values and beliefs that can lead to a greater meaning of a person's life. According to Spencer (2012), spirituality is a recognition of a feeling or sense or belief that there is something greater than myself, something more to being human than sensory experience, and that the greater whole of which we are part is cosmic or divine in nature. According to Asih et al. (2020), spirituality is more directed at the functional aspects of religion, or a more intrinsic dimension, while religiosity represents more substantive things or the extrinsic dimension of religion. Rituals are both tangible and intangible and they embody the religious and spiritual aspects.

The spiritual and religious nature of rituals are underpinned by peoples conceptions of life, death, religion and spirituality. In other words, how people make sense of life and death, and how such a sense or conception informs their practice of rituals, reveals their spiritual and religious conception posture. This is to suggest that the practice and understanding of the practice of funerary rites cannot be separated from an understanding of people's religion and spirituality. It is also during the practice of rituals where one can come to grips with people's religion and spirituality, which in general inform their worldview, or cosmology. For example, if one comes from a background of understanding death as a rite of passage, from one stage of life to another (into a new life), the rituals that are involved during this passing will symbolically 
represent this particular conception which may also be understood as their understanding of life after death or being born again - born 'again' into the spiritual world or spiritual realm of ancestors. In this case, funerary rites can be understood as mechanisms that bring about spiritual, cultural and religious preparation for salvation, for transition, etc. They may not bring one's salvation but the preparation is significant in the sense that it ensures a dignified burial of a person. It satisfies the application of the principles of culture and cultural sensitivity and traditional values. The preparation is significant also because it forms part of the aspects of mourning to comforts the family; because it affords the family the opportunity to burial their dead with respect and dignity behoving the ways of their family and clan. Furthermore, the preparation can be symbolic of the family's love of the deceased.

Now, ritual is touched with both the religious and spiritual, for like religion, which is described as that which is "re-read" and "is passed along chains of tradition" (Van Niekerk, 2018:2), rituals are passed along chains of traditions. Religion is a structured practice and, as already stated above, ritual is religion in action, or variously, a religious practice. Religion could be regarded as the host of ritual, and it hosts also "the conceptual aspects... such as beliefs, symbols, and myths", and ritual, "like action, will act out, express, or perform these conceptual orientations" (Bell, 1992:19).

Rituals are spiritual and purposeful and potent acts, and as such they are significant in man's view of life and worldview, they are also tied to people's sense of faith and belong (both physically and spiritually). The act of ritual has been adopted even by African writers such as Camara Laye in his autobiographical book, The African Child, where he reflects, reverently, on the ritual acts that his father, family and community conducted for different purposes. In the undertones of Laye's gaiety reflection on his communal (public) and immediate-family (private) upbringing and experience of ritual acts, the spiritual aspect of ritual is hinted at. Likewise, Masoga in his book entitled: Studies on Indigenous Knowledge, reflects on the national or public ritual of cleansing and reparation conducted by a collective number of religious and traditional sects as part of the Truth and Reconciliation (TRC) process, teases out other purposes of performing ritual acts, in private and/or public; and states that the "establishment of the TRC in South Africa has begun a ritual process" (Masoga, 2020:141).

Primarily, Masoga (2020) captures the fact that ritual has as one of its purposes the power to connect, reconnect and reconcile people, and not just on a physical level in the apparent structures of society, but also on a spiritual plane - public ritual. As far as death is concerned, ritual borders on the spiritual as a vehicle that connects and transports and "incorporates" (Van Gennep, 1960). For example, there are those rituals that are practiced for transition such as death, where a dead person is prepared for the journey from the world of the living to the world of spirits; and the family participating in the ritual for this purpose practice the ritual as some form of 'telegram' to connect and communicate with the ancestral spirit on behalf of the deceased, thus opening the spiritual passage through which the dead will travel to the other side.

Rituals are practiced with the belief that the deceased is now going to be part of the spiritual realm, as Masoga (2020) proffers that death is the beginning of new life. Some of the rituals involve spiritual invocations; others involve participants pouring libations and making fervent supplications, and burning incense to invoke a spiritual connection and presence. All these are the 'stuff of religion'. The spiritual aspect of ritual is revealed in rites such as those practiced at marriages as well. For example, at a wedding (marriage ceremonial rituals), especially of people who practice the Christian religion, a priest would guide the bride and groom and the attendees of the wedding to invite God to be part of the newlyweds' union (Strydom, 2019). The priest would perform this ritual by first reading a scripture that contextualises the purpose of the ritual and then effect it with a prayer, so that God (who is spirit) may be party to how the marriage is consummated. 


\title{
Culture and Adaptation
}

Covid-19 has brought about a coercive force against the face of culture, where cultures are met with an urgent and forceful demand to adapt to the new situation in the 'new normal' context of the pandemic. Culture influences people ostensibly because it provides them with an identity and a worldview through which they understand or interpret the cosmos (Iteyo, 2009). African culture and traditions are shown as deeply rooted in humanism such that the extension of which brought in the western stance invariably altered that peaceful understanding and coexistence enjoyed by the African people, as a result of varied outlook on ethical issues introduced by the white man (Edeh, 2015:206).

Explaining how Africans have always adapted to new progressions in nature without losing their sense of being, Mazama and Asante (2004) explain that,

The very survival of African people throughout history is due to this kind [interpretivist] of epistemology, which allowed people to assess the meaning of new realities in the light of old canons and to assess ancestral wisdom and customs in the light of new circumstances and wisdom.

It thus should be understood that a change of form in carrying out rituals performed in our cultures is a change of method and not a sign of disengaging from the rituals. Covid-19 lockdowns have been one of the many catalysts in history which led to the need for African people to re-imagine the form/method of carrying out our rituals. This adaptation has always been guided by the paradigms through which Africans understand the world. To speak of a "new normal" brought about Covid-19 is to explain a shift in the current course of how we lead our lives in light of the changes in the natural environment (where a virus has brought the need for physical distancing). This is not a shock for our cultures as they have always had to adapt to changing environments (Illich, 2010). Environment here is used to refer to the social, cultural, political, and natural ecology within which we live. With changes to the environment have come also adaptations of how best to lead our lives whilst keeping to the essence of who we are - a function of and expressed though rituals. For example, the advent of colonisation challenged the traditional modes of leadership in South Africa. However, traditional leadership still exists today and has found ways of coexisting with modern forms of government and governance (Logan, 2009:102).

\section{Culture and Change}

\section{The practiced stuff of ritual in the Covid-19 Context}

Culture is forever exposed to the possibility of change, for culture is dynamic in nature. Cultural 'stuff' such as ritual are also exposed to the possibility of change in time and through time. For Turner (1967:19), ritual is "prescribed formal behaviour for occasions not given over to technological routine, having reference to beliefs in mystical beings and powers". Deflem (1991:4) further adds that,

\begin{abstract}
Likewise, a symbol is the smallest unit of ritual which still retains the specific proper- ties of ritual behavior; it is a "storage unit" filled with a vast amount of information (Turner 1968a:1-2). Symbols can be objects, activities, words, relationships, events, gestures, or spatial units (Turner 1967:19). Ritual, religious beliefs, and symbols are in Turner's perspective essentially related.
\end{abstract}

In light of the definitions of symbol and ritual above, it is clear that rituals, like the cultures they exist within, are open to adapting to changes in their environment. What is also clear is that even if the manner of practicing them may change, the meaning and desire to preserve the rituals persist. Today technology or technological tools are being appropriated so as to facilitate a relevant and safe attendance of funeral services, thereby keeping in line with the strategic lockdown regulations. Culturally, and under normal circumstances, African people presented themselves physically to those families in which death has occurred to offer condolences and words of comfort. Today Covid-19 has inspired a sudden shift in how such 
cultural obligations are satisfied, where people, even relatives utilise technological platforms such as WhatsApp, Google Teams, Zoom, Skype and others to conduct the cultural practices that are related to death and funeral. It is worth mentioning that in other societies condolences in the form of money is a cultural practice, where community members and relatives offer physical money to the grieved family to ease financial strains during the unfortunate event. Now, in pandemics such as the Covid-19 situation such practices see the light of change, where technological tools such as Electronic Funds Transfer (EFT) are adopted to relevantly offer condolences and other financial support to families of the deceased. In a paper titled Effectiveness of WhatsApp homiletics in the era of COVID-19 in South Africa, Masoga (2020) studies how the technological WhatsApp tool is being used by churches to continue practicing the preaching of sermons, fellowship and worship. Of course he (Masoga) looks at a number of issues in the said paper, but primal is his survey on the use of WhatsApp as a tool for church practices in the context of Covid-19 in South Africa.

The new modes of practicing cultural obligations and expectations (from a safe distance through technology) upon the occurrence of death have not taken away the essence of communal mourning and support; they have only altered the manner in which these can take place, in adapting to the 'new normal', as per Mazama and Asante's (2004) assertion above. While positivist approaches of curbing the spread of Covid-19 have sought to emphasise the importance of limiting people's physical contact with each other, the spirit which has always kept people together continues to thrive through reimagining news ways of fulfilling their rituals.

\section{The suspended stuff of ritual in the Covid-19 Context?}

Whilst honouring the law prescribed under the lockdown regulations and seeking to preserve life, people were not able to meet in person as they would normally for funerals. Other restrictions of the lockdown in South Africa restricted the amount of time they could spend together at funerals. This has brought about a suspension of physical meeting and has led to the reimagining of how else essential funerary rituals may continue to be observed. In observing their rituals, African people often slaughter animals (such as a cow, goat, etc.) during funerals. This is done for ritual purposes (Lee, 2012:204), and for practical reasons such as providing food to the mourners. Mourners have had to reimagine new ways to observe the rituals, keep the dignity, and observe the sacredness of the departure of a loved one.

The lockdown restrictions and subsequent re-imagination thereof begs the question of whether Covid-19 has brought development to African funerary rituals. Here, it becomes important to read and understand changes in culture/ritual as adaptation, not development. In his discussion of Ubuntu and Development, Molefe (2019:109) shows that personhood precedes development. This is in light of how development and modernity have tended to describe change that seems to advance modernity as progress. We cannot see what is happening in the current times as superior to strategies used in the past (which is what "development" suggests). The conditions under which each group of people practicing culture required a different form of existence - thus all are equal, differing in form, not in essence.

\section{Re-imagining Funerary Rites}

When a person dies there are preliminary practices that are observes, such as the taboo practice of mourning, which occasions the marking of a family's ["those whom death, in its physical reality as placed in a scared, impure state" Van Gennep, 1960:147)] isolation from society And mourning, according Van Gennep, "is a transitional period for the survivors, and they enter through rites of separation and emerge from it through rites of reintegration into society (rites of the lifting of mourning, even cleaning rites)" (Van Gennep, 1960:147 emphasis added). Mourning is one of the several funerary rites. Funerary rites may be understood as rites that are practiced during the times of sorrow and pain caused by the passing of loved ones. These rites are brought about by the unprecedented occurrence of death. In an African 
context, the occurrence of death brings about the construction and practice of funeral rites. From an African sense, death is not a termination of life but a rite of passage from one stage to another. This transition is not a pleasant one. It is an occasion of sorrow and pain - caused by the passing of a fellow human being. It is the stage at which things are not functioning properly. Masoga (2020:134) counsels us that "The ritual is usually performed within the family when things are not running as they should." This is when and where the practice of funeral rituals is crucial, because just as Jindra and Noret also assert; "funeral rites serve to lessen the grief through the induction of the deceased into the collective memory, yet at the same time they are a means to bid farewell" (Jindra \& Noret, 2011:x).

Furthermore, funerary rites knit and strengthen unity, especially among the immediate family members of the departed and their ancestors (Jindra \& Noret, 2011). Funerary rites also strengthen social networks as they gather people together and bring them under the 'common denominator' of mourning, of honouring the dead and respecting principles of culture and tradition. Post-death interactions by family include discussions about the manner in which the person is to be mourned and buried, the place and time of burial, burial preparations, allocation of roles for the preparation of the funeral, preparation of the body (i.e., washing of the body, trimming of nails and hair, and dressing the body etc.); and the structure of the ritual to be performed as per tradition or the deceased's request or with regards to how the person has died (Graham, Gwyther, Tiso \& Harding, 2013; Jarred Martinl, Charles van Wijkl, Chesray Hans-Arendsel \& Luvuyo Makhaba, 2013). It is an irrefutable fact that when a person passes away, the remaining relative(s) need(s) varied kinds of support. Among such kinds of support are emotional support, spiritual support, psychological support, financial support, just to name but a few. It is during this time of loss where funerary rites are purposed to bring one into a process of healing. But, this healing also manifests itself in a form of gratification brought about by knowing that one's loved ones are buried with dignity - all necessary and relevant rites are practiced accordingly. This is because funeral rituals carry a particular essentiality in the people's biographies and sociality (both in conceptual and practical levels) which in their nature are neither permanent nor static. However, from a practical level, funeral rituals are not always active. They are, more often than not, evoked by an occurrence of death. This includes a manner in which it occurs and a place it occurs.

Funeral rituals practiced during the death of someone caused by car accident or murder, are not entirely distinct from those practiced, for example, when one died at his or her home. When one's death is caused by a car accident, immediate family members usually go to the scene of the accident or the hospital on a particular day and specific time to do what in Sepedi is called "Go tseya moriti or seriti sa gagwe, goba go tseya moya wa gagwe." Loosely translated, in English, it means "To take his or her shadow or dignity or to take his or her soul." The ritual practiced mostly depends on the family's traditions and culture. But more often than not, most families would go carrying branches of a specific tree deemed to be medicine, kneel down close to the place where his or her body was lying and perform rituals with the strong belief that he or she is listening to them, when they say that they taking him or her to his or her place of rest. In the process, they put the branches of tree exactly at the spot where the person departed. It is believed that if such a ritual is not practiced, the departed would not rest, and would consequently cause more accidents or even bring misfortunes to the family. This particular practice of a ritual is underpinned by an African conception of death - death as a rite of passage, and spirituality and being a human. The effect is both tangible and intangible.

\section{Among the Bapedi people, Masoga (1999a \& 2020b) indicates that:}

When death strikes in the family, a beast is slaughtered. The beast has to face the west to indicate the place of the dead. The east is seen as the place of the living. This binary opposition must always be maintained. Before the animal is slaughtered, the head of the family or clan has to 'speak' to it in a poetic manner. The animal is praised by the praise names of the deceased. Some of the oldest and most powerful ancestors and ancestresses are evoked to welcome a newcomer among them. At the same time, the deceased is 
informed about the long journey about to be undertake to the world of the living timeless.

Opong (2004) avers that the

\begin{abstract}
Basotho funeral rite as of old is full of ritual practices that punctuate the ceremonies from sickness to death and burial; and it is needless to say that most of these rituals have religious implications. When a person is seriously sick and on the point of death, the Basotho performed a recovery rite in the form of propitiatory sacrifice to appease the ancestor(s) the sick person might have of fended. (Opong, 2004).
\end{abstract}

Re-imagining funerary rites during and after the funeral necessitates an adoption of the view that like culture, funeral rituals are not in their nature permanent. Mazama and Asante (2004) indicate that "The very survival of African people throughout history is due to this kind [interpretivist] of epistemology, which allowed people to assess the meaning of new realities in the light of old canons and to assess ancestral wisdom and customs in the light of new circumstances and wisdom." Furthermore, Opong argues that "the interpretations of other ritual practices revealed that the core of their ritual acts lies in the fear and reverence for their ancestors whom they seek to appease or propitiate in order to bring sanity into the society and to prepare the deceased for life after death" (Opong, 2004:39). Moreover, the Covid-19 context or era is an anti-structure context, where structured practices such as rituals lose their religiosity and are thrust with a necessity for adaptations so as to remain relevant, even amidst the regulations put forward to curb the spread of the virus. In a way, the religious structures that frames funerary rites are evidently subject to the high possibilities of re-imagination.

Thus, it should be understood that a change of form in carrying out rituals is a change of method and not a sign of disputing the importance of rituals or its purpose. Covid-19 lockdowns have been among the many catalysts in history which led to the need for African people to re-imagine the form or method of carrying out rituals. To speak of a "new normal" brought about by Covid-19 is to explain a shift in the current course of how we lead our lives. This is not a shock for our cultures as they have always had to adapt to changing environments in the past. Environment here is used to refer to the social, cultural, political, and nature. With changes to the environment also came the need for the adaptation of how best to lead our lives in the best possible ways whilst keeping to the essence of who we are. For example, the advent of colonisation challenged the traditional modes of leadership in South Africa with modern and Western modes. However, traditional leadership still exists today and has found ways of coexisting with modernist forms of government and governance (Logan, 2009:102); in a way, leadership as South African people knew it was re-imagined so as to be relevant with the times and environment and new identities and societies.

Turner (1967:19) defined ritual as "prescribed formal behavior for occasions not given over to technological routine, having reference to beliefs in mystical beings and powers". Likewise, a symbol is the smallest unit of ritual which still retains the specific proper- ties of ritual behaviour; it is a "storage unit" filled with a vast amount of information (Turner, 1968a:1-2). Symbols can be objects, activities, words, relationships, events, gestures, or spatial units (Turner, 1967:19). Ritual, religious beliefs, and symbols are, in Turner's view, "essentially related" (Deflem, 1991:4). Turner views rituals or rites as symbolic, and that they inflect and effect an intense level of agency. The rites involve symbolic reference to all these agencies (Turner, 1969). Rituals are symbolic indeed, and some of the aspects that they symbolise are belief in the supernatural, reverence of God, or/and the gods, a moment of purification, admittance that people need blessings and protection from the higher, spiritual power(s) that might be, and the transition or passage.

In an interview held during the writing of this paper, Masoga argued that: 
Rituals are not permanent. They change from time to time, whereby new identities, new values and new communities are constructed, which subsequently evoke new notions of divinity (Masoga, 2021).

In light of the definitions of symbol and ritual above, it is clear that rituals, like cultures, exist within, and are open to adapting to changes in different environments. What is also clear is that even if the manner of practicing them may change, the meaning and desire to preserve the rituals persist; the purpose persists, which is the key feature of ritual. Thus, we observe today the appropriation of technology which allows people to attend funerals and other related obligations while keeping in line with the lockdown regulations.

As already mentioned above, these practices have not taken away the essence or purpose of communal mourning and support; they have only altered the way in which these can take place. While positivist approaches of curbing the spread of Covid-19 have sought to emphasise the importance of limiting people's physical contact with each other, the spirit which has always kept people together continues to thrive through re-imagining new ways of fulfilling rituals. The importance of reading and understanding changes in culture/ritual as adaptation, not development. We cannot see what is happening in the current times as superior to strategies used in the past (which is what "development" suggests). The conditions under which each group of people practicing culture required a different form of existence - thus all are equal, differing in form, not in essence.

Covid-19 has brought about a coercive force against the face of culture, where cultures are met with an urgent and forceful demand to adapt to the new situation in the 'new normal' context of the pandemic. Culture influences people ostensibly because it provides them with an identity and a worldview through which they understand or interpret the cosmos (Iteyo, 2009). African culture operates within the African philosophy of Ubuntu, and this philosophy encourages human creativity so that people may continuously care and support one another, beyond borders, colour lines and pandemics; the philosophy focuses on the person than established structures. Therefore, African cultures, guided by the philosophy of Ubuntu can adapt and have adjusted the manner in which they are practiced.

In re-imagining funerary rites, Bigger (2009:210) coalesces his views of ritual with those of Turner, and reveals that rituals are not about structure, rather about process, and the "process takes precedence over structure. Life is fluid, and messy. Structure can get undermined by these processes. So, the processes need to repair any breaches that might occur." Central in Bigger's assertion is the point that rituals, funerary rites in this case, have the capacity to inflect, and take up new 'structure', method in how they could still be best practiced in the "messy" Covid-19 context. Ritual has something of the nature of culture in that it is open to adaptation, adapting to new and "messy" situation. African people have placed religious, tradition and cultural value on rituals, therefore, it is pertinent to retain the practice of rituals, funerary rites, to seriously look into how new ways of practising the rites should take effect. As Bigger (2009) opined that ritual has still a central part to play in modern western society, with serious purposes (liminal).

\section{Conclusion}

It is clear that Covid-19 has created a space, a context where so much is suspended, challenged, perhaps even lost and thrust with urgent need for adaptation. There are those cultural and traditional experts who posit that the pandemic, and the lockdown regulations which were coined to curb the virus from spreading have upset the spiritual aspect of nations. Case in point is the spiritualist Mkhize, who states that "because people have been buried the wrong way, the country would have to perform a cleansing ceremony after the lockdown" (see SowetanLive, 2020). Mkhize's views are informed by the fact that many people were buried without proper funerary rites. Mkhize goes on to advise that "the government would need to consult with spiritual healers on how this should be done" (see SowetanLive, 2020). 
The researchers agree with figures like Mkhize, that indeed there has been 'strangeness' in the way many victims of the virus and other causes of death were buried. In lieu of this, the researchers argue that the rites of passage for the dead can be re-imagined and subsequently practiced in ways relevant and conscious of the context in which funerals are being conducted. As indicated above, rituals are not permanent in the manner they are practiced. Therefore, those rituals that require a certain person (such as a family member) who may not make it to a funeral (consequently not being present for the rites, such as the sharing of the deceased's clothing items, as practiced by the Pedi ethnic group) due to the lockdown regulations, such people could utilise technological gadgets and platforms to attend the rites. to reshape or repackage them for an era - this is the recommendation the paper is making.

Rituals oscillate between private and public, the personal and the communal; Covid-19 has affected mostly the public and communal types of rituals. For these types of rituals, people, can (for the sake of their safety (which is really our social responsibility) re-imagine meeting in person for a public or communal ritual by using technological platforms such as video calls (i.e. Google Teams, Zoom, Skype, Facebook Live Stream and YouTube Live Stream) and partake in rituals, for culture and tradition are not antithetical to technology. Of course, people have conducted funerals as if they were solitary affairs, and by so doing, they have disregarded the African philosophy of Ubuntu which encourages people's solidarity, communality and raising one another in times of distress.

If the Ubuntu philosophy is considered, its essential values can still be realised under the lockdown. People can formulate WhatsApp chat groups, where support systems and words of encouragement can be shared with the bereaved. Thus, new identities which merge out of the Covid-19 context, along with new values, can be well-forged and articulated. We conclude by saying that the most important aspect of a ritual is its purpose, rather than the method in which it is practiced. People can still purposefully practice rituals in the Covid-19 context in ways reimagined. The importance of rituals can be evinced whilst ensuring that compliance with the times we are in is maintained. We think that the purpose, function and impact of a ritual can still be realised in funerary rites. African funerary rites have been re-imagined before; "Xhosa traditional expert Zolani Mkiva said the state of disaster always existed in the past during wars and required people to be buried immediately when they die" (see SowetanLive, 2020).

Note: This forms part of the research project: Investigating local indigenous community perspectives in response to the COVID-19 pandemic: An invisible enemy in the midst of our local households, supported by the National Institute for Humanities and Social Sciences (NIHSS), under Health and indigenous knowledge systems (IKS) Research Cluster.

\section{Acknowledgment}

The authors would like to thank Professor Mogomme Alpheus Masoga, who gave them an opportunity to interview him on issues relating to them topic.

\section{Interview}

The authors conducted an interview with Professor Mogommme Alpheus Masoga (an expert in Indigenous Knowledge Systems, Ritual and Religion) on the nature of rituals and how rituals can be practiced in the context of Covid-19.

\section{References}

Al-Meshhedany, A.A.H. \& Al-Sammerai, N.S.M. (2010). Facing Finality: Cognitive and Cultural Studies on Death and Dying" Arabic Culture". English Language Teaching, 3(1), 12-15.

Asih, D., Setini, M., Dharmmesta, B. \& Purwanto, B. (2020). Religiosity and spirituality: Conceptualization, measurement and its effect on frugality. Management Science Letters, 10(16), 4023-4032. 
Andrews, H. \& Roberts, L. (2015). Liminality. In: Smelser N.J \& Baltes P.B. (eds.), International Encyclopedia of the Social and Behavioral Sciences. Oxford: Elsevier.

Asuquo, O.O. (2011). A rationalization of an African concept of life, death and the hereafter. American Journal of Social and Management Sciences, 2(1), 171-175.

Baloyi, M.E. (2014). Distance no impediment for funerals: Death as a uniting ritual for African people - A pastoral study. Verbum et Ecclesia, 35(1), 1-7.

Baloyi, L. \& Makobe-Rabothata, M. (2014). The African conception of death: A cultural implication. In L. T. B. Jackson, D. Meiring,F. J. R. Van de Vijver, E. S. Idemoudia, \& W. K. Gabrenya Jr. (Eds.), Toward sustainable development through nurturing diversity: Proceedings from the 21st International Congress of the International Association for Cross-Cultural Psychology.[Available online at https://scholarworks.gvsu.edu/iaccp_papers/119]

Bigger, S. (2009). Victor Turner, liminality, and cultural performance. Journal of Beliefs \& Values, 30(2), 209-212.

Bell, C. (1992). Ritual theory, ritual practice. Oxford University Press.

Bamford, M. (2020). Desktop Study (Phase 1).

Banasick, S. (2019). KADE: A desktop application for Q methodology. Journal of Open Source Software, 4(36), 1360.

Cohen, M. (2002). Death ritual: Anthropological perspectives. Perspectives on Death and Dying, 7.

Deflem, M. (1991). Ritual, anti-structure, and religion: A discussion of Victor Turner's processual symbolic analysis. Journal for the scientific study of religion, 1-25.

Diawuo, F. \& Issifu, A.K. (2015). Exploring the African traditional belief systems in natural resource conservation and management in Ghana. The Journal of Pan African Studies, 8(9), 115-131.

Ekore, R.I. \& Lanre-Abass, B. (2016). African cultural concept of death and the idea of advance care directives. Indian Journal of Palliative Care, 22(4), 369.

Foronda, C.L. (2008). A concept analysis of cultural sensitivity. Journal of Transcultural Nursing, 19(3), 207-212.

Freud, S. (1938). Totem and Taboo (807-930). New York: Modern Library.

Graham, N., Gwyther, L., Tiso, T. \& Harding, R. (2013). Traditional healers' views of the required processes for a "good death" among Xhosa patients pre-and post-death. Journal of pain and symptom management, 46(3), 386-394.

Hlatshwayo, M.N. (2020). The emergence of the lockdown university: Pitfalls, challenges, opportunities. Alternation African Scholarship Book Series (AASBS), 133.

Hollis, M. (1994). The philosophy of social science. Cambridge, UK: Cambridge University Press.

Illich, I. (2010). Needs. In: Sachs, W (ed.), The development dictionary: A guide to knowledge as power. London: Zed Books.

Iteyo, C. (2009). Belief in the spirits of the dead in Africa: A philosophical interpretation. Thought and Practice, 1(1), 151-163. 
Khan, I., Shah, D. \& Shah, S.S. (2020). COVID-19 pandemic and its positive impacts on environment: an updated review. International Journal of Environmental Science and Technology, 1-10.

Khoza, R.J. (2005). Let Africa lead: African transformational leadership for 21st century business. Johannesburg: Venzubuntu Publishing.

Lee, R. (2012). Death in slow motion: Funerals, ritual practice and road danger in South Africa. African Studies, 71(2), 195-211.

Logan, C. (2009). Selected chiefs, elected councillors and hybrid democrats: Popular perspectives on the co-existence of democracy and traditional authority. The Journal of Modern African Studies, 47(1).

Lefa, B.J. (2019). The African philosophy of ubuntu in South African education. Master's Dissertation. Cape Town: Cape Peninsula University of Technology.

Lutz, D.W. (2008). African ubuntu philosophy and philosophy of global management. Catholic University of Eastern Africa, Nairobi.

Masoga, M.A. (2020). Effectiveness of WhatsApp homiletics in the era of COVID-19 in South Africa, Pharos Journal of Theology, 101.

Masoga, M.A. (1999). Towards sacrificial-cleansing ritual in South Africa: An indigenous African view of truth and reconciliation. Alternation, 6(1), 213-224.

Mazama, M.A. \& Asante, M.K. (eds.). (2004). Encyclopedia of black studies. New York: SAGE Publications.

Molefe, M. (2019). Ubuntu and development: An African conception of development. Africa Today, 66, 115-197.

Mbiti, J.S. (1980). African religions and philosophy. London: Heinemann.

McKee, A. (2001). A beginner's guide to textual analysis. Metro Magazine: Media \& Education Magazine, (127/128), 38-149.

Mousazadeh, M., Paital, B., Naghdali, Z., Mortezania, Z., Hashemi, M., Niaragh, E.K., Aghababaei, M., Ghorbankhani, M., Lichtfouse, E., Sillanpää, M. \& Hashim, K.S. (2021). Positive environmental effects of the coronavirus 2020 episode: a review. Environment, Development and Sustainability, pp.1-23.

Nyamnjoh, F.B. (2012). Blinded by sight: Divining the future of anthropology in Africa. Africa Spectrum, 47(2-3), 63-92.

Opong, A.K. (2004). Some religious aspects of Basotho funeral rituals. Journal for the Study of Religion, 25-45.

Park, C. (2020). Traditional funeral and burial rituals and Ebola outbreaks in West Africa: A narrative review of causes and strategy interventions. Journal of Health and Social Sciences, 5(1), 073.

Rafapa, L.J. (2005). The representation of African humanism in the narrative writings of Es' kia Mphahlele (Doctoral dissertation, Stellenbosch: University of Stellenbosch).

Sebola, M. \& Mogoboya, M. (2021). Es' kia Mphahlele's In Corner B: Humanising Africans in a Dehumanising Epoch. Journal of Critical Reviews, 8(2), 367-378.

Segal, R.A. (1983). Victor Turners theory of ritual. Zygon, 18(3), 327-335.

Senthilingam, M. (2020). Outbreaks and epidemics: Battling infection from measles to coronavirus. Icon Books. 
Shokane, A.L., Masoga, M.A. \& Blitz, L.V. (2020). Creating an Afro-sensed, communityengaged School: Views from parents and school personnel. Journal of Progressive Human Services, 31(2), 107-125.

Singh, J.A. (2020). How South Africa's ministerial advisory committee on COVID-19 can be optimised. South African Medical Journal, 110(6), 439-442.

Smith, F.T. (1987). Death, ritual, and art in Africa. African Arts, 21(1), 28-84.

Strydom, M. (2019). Wedding rituals in Christianity, Judaism and Islam: A science of religion perspective. Doctoral dissertation. University of Pretoria.

Thanh, N.C. \& Thanh, T.T. (2015). The interconnection between interpretivist paradigm and qualitative methods in education. American Journal of Educational Science, 1(2), 24-27.

Turner, V., Abrahams, R.D. \& Harris, A. (2017). The ritual process: Structure and antistructure. Routledge.

Turner, V. (1974). Liminal to liminoid, in play, flow, and ritual: An essay in comparative symbology. Rice Institute Pamphlet-Rice University Studies, 60(3).

Turner, V.W. (1967). The forest of symbols: Aspects of Ndembu ritual. Ithaca: Cornell University Press.

Ukwamedua, N.U. (2018). The ontological status of 'The Living Dead' in postmodern African: A discourse in existential metaphysics. UJAH: Unizik Journal of Arts and Humanities, 19(1), 24-40.

Van Niekerk, B. (2018). Religion and spirituality: What are the fundamental differences? HTS: Theological Studies, 74(3), 1-11.

Wallace, A.F.C. (1966). Religion: An Anthropological View. New York: Random House. 